Chapter Title: Three Ancient Manuscripts from Tholing in the Tucci Collection, IsIAO, Roma, Part II: Manuscript 1329 O

Chapter Author(s): AMY HELLER and CHARLOTTE ENG

Book Title: Interaction in the Himalayas and Central Asia

Book Subtitle: Process of Transfer, Translation and Transformation in Art, Archaeology, Religion and Polity

Book Editor(s): EVA ALLINGER, FRANTZ GRENET, CHRISTIAN JAHODA, MARIA-

KATHARINA LANG, ANNE VERGATI

Published by: Austrian Academy of Sciences Press. (2017)

Stable URL: https://www.jstor.org/stable/j.ctt1pv891n.13

JSTOR is a not-for-profit service that helps scholars, researchers, and students discover, use, and build upon a wide range of content in a trusted digital archive. We use information technology and tools to increase productivity and facilitate new forms of scholarship. For more information about JSTOR, please contact support@jstor.org.

Your use of the JSTOR archive indicates your acceptance of the Terms \& Conditions of Use, available at https://about.jstor.org/terms

This book is licensed under a Creative Commons Attribution-NonCommercialNoDerivatives 4.0 International License (CC BY-NC-ND 4.0). To view a copy of this license, visit https://creativecommons.org/licenses/by-nc-nd/4.0/.

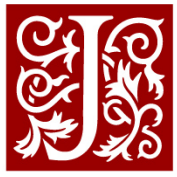

Austrian Academy of Sciences Press is collaborating with JSTOR to digitize, preserve and extend access to Interaction in the Himalayas and Central Asia 


\section{Three Ancient Manuscripts from Tholing in the Tucci Collection, IsIAO, Roma, Part II: Manuscript 1329}

Dedicated in honor of the memory of our friend and esteemed colleague Tsering Gyalpo (T.G. King), deceased June 27, 2015, who accompanied Amy Heller in research from 1995 at the Tibet Academy for Social Sciences, Lhasa (sku gsung thugs kyi dgongs par rdzogs so).

At the 2013 SEECHAC colloquium "Interaction in the Himalayas and Central Asia: processes of transfer, translation and transformation in art, archaeology, religion and polity from antiquity to the present day" Amy Heller presented recent research on three previously unpublished Tibetan Buddhist manuscripts whose codicology and art historical analysis shed further light on the distinctive characteristics of manuscripts collected by Professor Giuseppe Tucci during his travels in Western Himalayas and Western Tibet 1933-1937 (Tucci and Ghersi 1996 [1934, Tucci 1937, 1949, 1989 [1937] and De Rossi Filibeck 1996; 2003). These manuscripts are part of a well-known corpus produced in the context of the $10^{\text {th }}$ to $11^{\text {th }}$ century revival of Buddhism promoted by the royal patronage of the Kingdoms of GugePurang, at the royal monasteries of Tholing in Guge and Khorchag in Purang. The present paper is focused on (1) the historic context of the manuscripts and their artistic provenance, (2) Charlotte Eng's scientific observations on colorants, including gold, and technical observations on the process of preparation, painting, and surface treatment, and (3) codicological remarks and art historical analysis of the Tholing manuscript $1329 \mathrm{O}$ of the Tucci Archive of the Istituto Italiano per l'Africa e l'Oriente, Roma. ${ }^{1}$

1 Amy Heller thanks Prof. Elena De Rossi Filibeck for inviting her to Rome as visiting professor to study these illuminated manuscripts of the Tucci archive

\section{HISTORIC CONTEXT}

The West Tibetan manuscript tradition spread in the three kingdoms of Guge-Purang and Mar yul, which straddled the Himalayas over regions of modern India (portions of Spiti, Kinnaur, Zangskar and Ladakh), as well as north-western Nepal (Limi-Humla-Dolpo) and the western reaches of the Tibetan Autonomous Region (Harrison 2009: xv). In this vast territory, under the impetus of the royal lineage governing the three kingdoms, Kashmiri and Bengali panditas were invited to clarify and translate the Buddhist teachings into Tibetan (see Tucci 1988 [1932]: 37-49); Kashmiri artists were invited to Tholing following the royal edict which required aesthetic perfection and production by local workshops for the creation of Buddhist art (Vitali 1996: 111). Historic records document their active collaboration with Tibetans as well as some artists from Nepal (ibid.: 263), even artists from Magadha (ibid.: 313) to produce sculptures and mural paintings to honor the newly established sanctuaries and monasteries. The production and dissemination of Buddhist manuscripts, particularly illuminated manuscripts of the Prajñāpāramitā literature, was at the very crux of this context of intense multi-cultural religious transfer and artistic transformations stemming from the cult of the book of Mahāyāna Buddhism, expressed by the donations of manuscripts

and Prof. Franco D'Arelli, director of the IsIAO for authorizing their photography and publication. She is grateful to Dr Stephen Markel, curator of South Asian Art and Dr. Charlotte Eng, conservation scientist at Los Angeles County Museum and Dr. Charlotte Eng, conservation scientist at Los Angeles County Museum
of Art for their help in studying the Tholing manuscripts now in the LACMA collection. 
of Mahāyāna sūtras. ${ }^{2}$ Descriptions of scribes and scriptoria in Dunhuang and Tibetan participation in this are well documented (van Schaik 2007, Takeuchi 1995: 53-59, Scherrer-Schaub 1999). Consequently, although lacking archeological data, it has been presumed that at Tholing, a scriptorium was established shortly after the foundation of the monastery, that many of the sütras were copied where the money was, in the centre of the kingdom, and then distributed to the religious foundations in the area. ${ }^{3}$ Several colophons of Buddhist texts were translated at Tholing in the second half of the $11^{\text {th }}$ century by a scion of the Guge royal family, thus it is certain that scribal activities occurred in situ (Karmay 1980). Insofar as Tucci was in possession of many volumes of Buddhist manuscripts, some of which he and later Dr. Eugenio Ghersi found in caves above Tholing, formerly used by the monks as their winter residence (Tucci and Ghersi 1996: 306), it is believed that many of these manuscripts may have been produced in situ (De Rossi Filibeck 2007). While it is simultaneously possible that "scribes could have been itinerant, like their fellow artists," (Scherrer-Schaub 2008: 315, n. 31), particularly the production of richly illuminated manuscripts of the Prajñāpāramitā in situ in Tholing constitutes a concrete reflection of the royal edict to promote artistic and scribal excellence to foster the implantation of Buddhism.

The Tibetan translations faithfully retain the wording of the Indian antecedents of the text, but it is characteristic that the manuscripts of the Prajñāpāramita found at Tholing are written in Tibetan, in an elegant and stylized calligraphy of the highest quality. ${ }^{4}$ Further transformation from the original Indian models is reflected by the support, for rather than the long and narrow birch-bark, palm leaves and claycoated paper used in their Indian antecedents, these Prajñāpāramitā manuscripts are written on large sheets of smooth beige paper, ca.

\footnotetext{
2 See Will Tuladhar-Douglas 2009 and Gudrun Melzer 2014.
}

3 Paul Harrison, August 14, 2007 (personal communication). Ca. 1000-1020 A.D., donation of multiple copies of Prajñāpäramitā manuscripts to many new foundations are described in the biography of Rin chen bzang po (Tucci 1988 [1932]): his personal translations as well as those of many translators active at Tholing are attested in numerous colophons of the Buddhist canon, culminating in the 1076 Buddhist Council (chos 'khor) at Tholing where Indian and Ka in the 1076 Buddhist Council trine and translation (Shastri 1997).

4 The Tucci collection manuscript $1329 \mathrm{E}$ is studied in "Three ancient manuscripts from the Tucci Collection, ISIAO, Part I" to be published in the proceedings of the 2014 Luciano Petech Centenary Symposium, edited by Osc ins lesini and Elena De Rossi Filibeck (Heler, in press). Amy Hiller thanks Elen De Rossi Filibeck for inviting her to Rome as visiting professor to study these manuscripts, of which $1329 \mathrm{O}$, is the focus of the present article, and $1329 \mathrm{~F}$ is a forthcoming study.
20-27 x $68 \mathrm{~cm} .{ }^{5}$ Similar-scale pages are known among the Tibetan Śatasāhasrikā Prajñāpāramitā manuscripts from Dunhuang, although there are no illuminations among the extant leaves of beige paper. ${ }^{6}$ The scale of the Tibetan letters is proportionately larger than the Indian script, although the binding holes of the palm leaves are still indicated by the presence of two small circles $(\mathrm{ca} .2 .7 \mathrm{~cm}$ ) in the central portion of the sheet, which were not pierced, and thus are purely a visual reminder of the Indian custom of stringing the leaves or pages together. A further characteristic of the enlarged scale and paper support of the Tholing Śatasāhasrikā Prajñāpāramitā is the presence of elaborate illuminations which adorn these manuscripts. One must recall that the oldest dated illustrated Sanskrit manuscript now extant was produced in AD 997 in India, while the oldest dated illustrated Nepalese manuscript was produced in AD 1015, both are palm leaf manuscripts which support restricts the painter (Jamieson 2000). Thus the paintings in the Tholing manuscripts of late $10^{\text {th }}$ to $11^{\text {th }}$ century constitute a logical progression adapted to the finely finished Tibetan paper which afforded the painters with a support allowing opulent embellishment, among the finest examples known today being the aspect of Prajñāpāramitā in six arms (Fig. 1) now in the collection of the Los Angeles County Museum of Art (LACMA).

Tucci considered that the leaves of the Tholing Śatasāhasrikā Prajñāpāramitā illuminations reflect the aesthetic matrix of ancient artists of Kashmir in consideration of the carved wooden door-frames of Tholing and Tabo and the mural paintings he examined in nearby Mang nang, due to the royal invitation of Kashmiri artists as well as Kashmiri panditas (Tucci 1949: 273). Subsequent archaeological investigations inside a stūpa in Tholing revealed mural paintings and fragmentary painted clay sculptures which considerably add to our understanding of the palette of brilliant colors and abundant use of gold, particularly the sculpture of a standing, golden-bodied Buddha and a dark blue Bodhisattva wearing garments painted to represent exquisitely detailed geometric patterned textiles similar to those of

5 Melzer 2014 studies a birch-bark manuscript $10 \times 50 \mathrm{~cm}$, while Losty 1982 gives palm-leaf dimensions as $3-5 \mathrm{~cm} \times 54 / 5660 \mathrm{~cm}$ in length, and the Gilgit pages ca. $3 \times 7 \mathrm{~cm}$.

6 van Schaik (2007) discusses the large leaves of Śatasāhasrikā Prajñāpāramitā still in Dunhuang as well as those now in collections in Europe and Japan, referring notably to the research of Marcelle Lalou (1964). Amy Heller thanks Sam van Schaik for correspondence on the lack of gold illuminations in the Tibetan Prajñāpāramitā manuscripts among the Dunhuang collections. See also Helman-Ważny (2014).

See Heller (in press) for the study of the radiocarbon analysis of the LACMA M.81.90.6 which is $986-1030$ A.D., $95 \%$ confidence. 
the miniatures in the manuscripts (Fig. 2). ${ }^{8}$ The jewelry and crowns in the mural paintings are painted with genuine gold, the pattern of the textiles is highlighted with gold just like those of the illuminations. ${ }^{9}$

The source of this gold leaf or gold powder may well be gold fields near Tholing, which were already being actively exploited by 100 miners and their families in the early $11^{\text {th }}$ century under royal edict. ${ }^{10}$ The presence of a brilliant gold circular body aura surrounding the Buddha, Bodhisattva or goddess is characteristic of seven of the twelve Tholing Prajñāpāramitā manuscript leaves which, according to the most thorough subsequent study of the twelve leaves from the collection of the Los Angeles County Museum of Art by Paul M. Harrison (2007), constitute a series. He focused on the codicological aspects and the actual text of these manuscript leaves, as well as identification of the deities and goddesses represented on them. The actual participation of Kashmiri artists in the production of the Tholing manuscripts is documented by Harrison's observation of "traces of faint red (or in one case, black) lettering in an Indic script beneath the frames (of the illuminations), which was deliberately effaced [...]. Evidently the text was copied first, leaving spaces for the illustration, after which these annotations were made, then the painting area was prepared with a light coat of white plaster, on which the paint and lastly the varnish were applied." (Harrison 2007: 235). The presence of these letters considerably strengthens the likelihood that these illuminations were painted by Kashmiri artists, presumably working in tandem with Tibetan scribes under royal commission.

\section{TECHNICAL REMARKS}

Scientific examination of the illuminated leaf of the Tholing manuscripts that depicts Prajñāpāramitā with devotees (Fig. 1), has allowed identification of the colorants used in the paint; notably the use of gold leaf has been documented contrary to the earlier Ti-

8 We thank Zong Tong-Chang for permission to publish his photo, 1999.

9 Personal communication by Thomas J. Pritzker, July 1999.

10 The vast use of gold-tens of thousands of units zho of gold and copper (yo byed gser zho khri tsho zangs) whether for production of an 18 volume se of Prajñāpāramitā sūtras or a statue of (solid) gold the size of a fist, a golden stūpa-is recorded in $16^{\text {th }}$ century Tibetan historical literature $\left(m N g a^{\prime}\right.$ ris chos 'byung, ed./translation Vitali 1996: $62-63,116)$. In the $12^{\text {th }}$ century the historian Nyang ral Nyi ma 'od zer (1988: 461) described the gold fields of Dong rtse wang, where abundant gold was mined to build temples of Khorchag, Tabo, Nyarma and Tholing. Nyarma and Tholing. See Thomas. Pritzker (2008. 103) for the location of gold fields near Tholing. The edict of the Guge sovereign tha bla ma Ye shes 'od (947-1024) is cited by Ra se Dkon mchog rgya mtsho 2004: 121. Amy Helle thanks Guntram Hazod for this reference. betan Prajñāpäramitā leaves discovered among the Dunhuang manuscripts and the contemporaneous Indian and Nepalese painted palm-leaf manuscripts now extant. ${ }^{11}$ The colorants used in this illuminated leaf are consistent with those available in the time period when the manuscript was created, ${ }^{12}$ with radiocarbon analysis of two samples of the leaf of paper yielding six subsamples with consistent readings. The weighted mean radiocarbon age from this calculation was 1019 +/- 19 radiocarbon years BP ("before present"). The calibration generated a single peak; which yields a calendar age span of AD 986 to AD 1030 at $95 \%$ confidence. ${ }^{13}$

Colorants identified using a combination of portable X-ray fluorescence (pXRF) spectroscopy, Fiber Optics Reflectance Spectrosopy (FORS) and digital microscopy are as follows (for details of the instrumentation used in the examination, see Eng 2013: 20):

Blue: instead of blue inorganic pigment such as azurite, indigo was used. This plant-derived colorant could have come from India; where it was first mentioned used in manuscripts in the $4^{\text {th }}$ century BCE.

Red: the painted red contains mercury and sulfur. The pigment used was likely ground cinnabar mineral, a mercuric sulfide compound used as a pigment since antiquity. Alternatively, it could be the synthetic form of mercuric sulfide, vermilion. In addition to mercuric sulfide, an organic red lake was also used to paint details and for glazing. Identification of the lake was not possible with the nondestructive analytical methods used in the study of this work of art.

11 Jeremiah Losty (1982: 17) discusses the difficulties of decorating palm-leaf manuscripts, in particular to fix gold to the surface. The earliest extant indigo manuscripts, in particular to fix gold to the surface. The earliest extant indigo
tinted paper manuscript with gold and silver ink was found in Dunhuang, a Chinese manuscript of Lotus sutra dated to the 8th century, lacking illustration (Pelliot Chinois 4512). There are no Tibetan manuscripts on beige paper with gold illuminations among the corpus of Tibetan manuscripts from Dunhuang See van Schaik, Helman-Ważny and Nöller 2015. Losty considers that the popularity of painted wooden covers, especially in western India and Kashmir, had a period of deviopment before AD 1000 at a time when illumination mad a peiod of developm leaf was relatively more difficult and complex technically, as exemplified by the painted Kashmiri book cover radiocarbon dated to the $10^{\text {th }}$ century (Pal 2007: 104, fig. 108; Pal 2008).

12 Remarks in regard to the preparation of the white ground prior to painting on the paper support the observations of conservator Jean-Michel Terrier in regard to preparation for painting on cloth in a distinctive white ground, a techregard to preparation for painting on cloth in a distinctive white ground, a tech-
nique specific to thangkas of western Himalayas in a Kashmiri aesthetic matrix nique specific to thangkas of
(see Heller 2014 and 2015).

13 "Radiocarbon Dating Tibetan Manuscript M 81.90.6 from Los Angeles County Museum of Art", 23 February 2010, analysis by Dr. Greg Hodgins, Arizona Accelerator Mass Spectrometry Facility, University of Arizona. We thank Dr Stephen Markel in his capacity as curator, for authorizing the 32.1 microgram Stephen Markel in his capacity as curator, for authorizing the 32.1 microgram
sample to perform the radiocarbon analysis, and for sponsorship of the cost of the examination. 
Yellow: yellow areas contain orpiment, a pigment that contains arsenic and sulfur. Orpiment is a soft mineral that was used since antiquity.

Green: a mixture of indigo and orpiment is found in the green areas.

White ground: The ground contains both clay and calcium sulfate (gypsum).

Black: black areas are highly infrared absorbing, suggesting the pigment is carbon-based, and most likely lamp-black.

Gold: gold leaf was used for the jewelry. Some smaller details could possibly have been executed with paint containing gold powder.

In terms of the technique, a number of observations were made when the manuscript leaf was examined under high magnification using a digital microscope:

Underdrawing: examination using the digital microscope shows that a faint pink-colored line was brushed onto the support to outline the illuminated section of the manuscript prior to the application of the white ground. Underdrawing applied on top of the ground or in the paint layers could not be found using infrared reflectography, evidence of some red underdrawing can be seen under the microscope. This suggests the underdrawing material is not particularly infrared absorbent

Ground: With the pink line used as a guide, the white ground layer was applied onto the paper. It appears that when the ground dried, a characteristic crack pattern was formed. Despite the development of the cracks, the subsequent paint layers were applied on top of this ground layer. In some areas, paint seeped down into the cracks. In other areas, there was incomplete coverage of the cracks by the paint.

Preparation layer: There may be a yellow orpiment containing wash that was applied onto the ground, but this would have to be confirmed with cross-section samples. On top of this yellow wash, some evidence of red underdrawing can be found.

Border: the borders of the illuminated area included an orange wash and organic red colorant.

Background: in the painted area, flat colors are applied over the ground and yellow preparation layer. To make the red background richer, it was glazed with a red lake after the figures were painted. In some cases, the red glaze is painted over the figure while in others, the glaze incompletely covers the red background.

Figure: the main figure appeared to be drawn first in red on top of the yellow layer. An orange wash was applied along the outline for shading. Fine details of the facial features were painted with black and a red lake. Gold was used for the jewelry, which was then accented with red lake.
Coating: the overall image has been coated with a layer of shellac Perhaps the shellac was used to protect the underlying paint layers and is the varnish Harrison mentions in his study of the manuscript leaves.

Inscription: the inscription was made with a fluid, carbon-based (likely lamp-black) ink. Binding media were not identified, due to the interference of the carbon-based pigment. There is a two-tone appearance in some of the characters, suggesting the calligrapher sometimes re-dipped his brush during the inscription of a character.

\section{ISIAO MANUSCRIPT 1329 O}

The present leaf (Fig. 3) is the first folio of volume Cha-Na, an incomplete text of the Śatasāhasrikā Prajñāpāramitā, $67 \times 20.5 \mathrm{~cm}$, with the script in ten lines. The manuscript comprises folios $1 a-15 b$, 29a-104b (De Rossi Filibeck 2003: 437-8). Folio 1a which has two illuminations will be studied here. Both appear to be the work of one artist working in a Kashmiri aesthetic matrix which technically emphasizes the modeling of the volume of the body by chromatic nuances as described previously in the LACMA manuscript leaf; both the representation of the Goddess Prajñāpāramitā and the Buddha are surrounded by the brilliant gold body aura found on the seven leaves of the Tholing series identified in LACMA. Folio 1a has the two illuminations symmetrically sized and positioned at left and right of the main text; this leaf is the start of section 128 , with double siddham; it is merely numbered "gcig" without volume indication, however the first line of the text indicates that this is vol. Cha, section $28 .{ }^{14}$ On folio $13 \mathrm{~b}$, the beginning of section 129 is preceded by

14 No chapter is indicated, just the volume and the section. The full text of the leaf reads as follows:

shes rab kyi pha rold tu phyind pa stong phrag brgya pa / dum bu drug pa / bam po brgya nyi shu rtsa brgyad pa// //ko'u shi ka stong spyi phud kyi 'jig rten gyi khams Ita (line 2) zhog gi/ ko'u shi ka stong gnyis pa bar ma'i 'jig rten gyi khams kyi sems can ji snyed pa de dag rigs kyi bu 'am rigs kyi bu mo gang la las dge ba bcu'i las kyi lam (la - m overscript) (line 3 ) la bkod na/ko'u shi ka 'di ji snyam du sems/ rigs kyi bu 'am rigs kyi bu 3) la bkod na/ko'u shi ka 'di ji snyam du sems/ rigs kyi bu 'am rigs kyi bu mo de gzhi de las bsod nams mang du skyed dam/gsold pa bcom Idan 'das (line 4) mang lags so/ bde bar gshegs pa mang lags so/ bcom Idan 'das kyis bka' stsald pa (horizontal ligatures in combination with refined calligraphy) / ko'u shi ka de bas rigs kyi bu am rigs kyi bu mo gang (line 5) gis shes rab kyi pha rold tu phyind (circle of binding) pa'i glegs bam bri ba dang/ klag (sic klog?) pa dang/ ko ton tu bya ba'i phyir ga (circle of binding) zhan (! =gzhan) dag la byin na bsod nams ches( line 6) mang du skyed do/ de ci'i phyir zhe (circle) na/ ko'u shi ka de ni 'di ltar shes rab kyi pha rold tu phyind pa 'di (circle) las zag pa myed pa'i chos rnams (line 7) rgya cher bstand te/ de dag la bslabs nas/ rigs kyi bu am rigs kyi bu mo dag yang dag pa'i skyon/ myed pa la zhugs par gyurd to/ 'jug (line 8) go/ 'jug par 'gyur ro/ /rgyund tu zhugs pa'i 'bras bu thob par gyurd to/'thob bo/ thob par 'gyur ro/ /lan cig phyir 
a single siddham lacking decoration and the leaf has no illumination. The text is written in elegant calligraphy in Tibetan dbu can script with archaisms: da drag and ya btags are common, there is one instance of superabundant ' $a$. Other features are tsheg before shad for all letters, and the horizontal ligatures for $r$ ts and sts.

The siddham is double, ornamented top, vertical to $12+|| .^{15}$

There are two binding holes surrounded by circles in red ink, the margins are also drawn in red ink, folio $1 b$ is blank except for the lines of the two margins in red and the red circles of the binding holes.

Illuminations: at left, enshrined Prajñāpāramitā, $9.2 \times 8 \mathrm{~cm}$; at right, enshrined Buddha, $9.1 \times 7.6 \mathrm{~cm}$.

\section{A. Prajñāpāramitā}

Prajñāpāramitā (Fig. 4) is seated in the middle of a chamber guarded by two lions which flank a finial in the shape of a stylized dharmacakra. Inside the horizontal roof lintel, there is a polylobate arch which frames the red circular halo which comes to a point over her head. A circular rainbow halo surround is filled in brilliant gold (leaf?), so thickly applied that there are minor cracks in the gold. She is crowned and wears elaborate circular gold hair ornaments. The forehead is graced by small curls with the point of the central crown ornament as a middle part of the hairline. Her forehead is broad with a vertical urna $\bar{a}$ at the level of the fine lines of the eyebrows. Delicate shading of the flesh tones of the face in red to orange to pale orange with white highlights are characteristic of the Kashmiri taste for modeling the volume of the body by shading. ${ }^{16}$ The eyes are almond shaped with

(line 9) ong ba'i 'bras bu thob par gyurd to/ 'thob bo/ thob par 'gyur ro/ / phyir myi 'ong ba'i 'bras bu thob par gyurd to/ 'thob bo/ thob par 'gyur ro/ /dgra bcom ba' nyid (line 10) thob par gyurd to / 'thob bo/ thob par 'gyur ro/ rang sangs rgyas kyi theg pa pa rnams kyis/ rang byang chub thob par gyurd to/ 'thob po/ thob par 'gyur ro/

In line 5 , the circle of the binding hole interrupts the word gzhan, with ga written at left of the circle and zhan at right. This indicates that the scribe wrote the text after the circle of the binding hole was drawn. This follows the order of work described by Lalou for the Tibetan scriptoria of Dunhuang (Lalou 1954).

15 The archaisms in spelling and the scribal marks are identical with those on the Tholing leafs studied by Harrison 2007. This description of the siddham or mgo yig is according to conventions developed for the sütra volume of the Tabo catalogue (Harrison 2009), which note whether the siddham is single, double or triple, whether it is plain or adorned on top or bottom, what direction it curls towards (expressed in terms of the numbers on a clock face), and whether the two shad which typically follow it enclose two tsheg (usually side by side / .. /, sometimes one above the other / : /) or a blank space (/ /).

16 See Chakrabarti (1980: 85-88) for the explanation and terminology of shading techniques in Indian painting treatises. red lines at the lower eyelid. Her nose and lips are small, the chin is slightly rounded. She wears garments typical of Kashmiri goddesses and aristocratic donors, ${ }_{1}^{17}$ notably the distinctive short-sleeved blouse cut to reveal her midriff; here it is green with a small red geometric pattern. At her shoulders she has a pale yellow scarf with tie-dye red circles, the lower section of the scarf is red as it drapes along her elbows, ending with the yellow fabric which flutters above her thighs. She has a long double-strand of pearls with two circular medallions at the level of her navel, the necklace beyond her feet with another circular medallion at the center of the lotus-petal cushion on which she is seated. Her upper right hand holds a vajra with three open prongs, the central hands form the dharmacakramudrä, her upper left hand holds the pothi volume of the eponymous sūtra. She wears a dhoti patterned in horizontal stripes and small geometric motifs. Her palms and the soles of her feet are red, symbolic of henna adornment customary in India, Kashmir and Nepal. The soles of the feet have the auspicious mark of three dots forming an equilateral triangle. She is seated on a pink cushion above the elongated lotus petals in multilayer configuration above a scarf with circular tie-dye patterns.

The aspect of the four-armed Prajñāpāramitā is frequently illustrated in the leaves of ancient Prajñāpäramitā texts, although the vajra of her upper right hand is sometimes replaced by a small strand of prayer beads. The distinctive vajra with open prongs is also held by the Prajñāpāramitā in the Tholing manuscripts in the LACMA collection (Fig. 1), who has similar hair ornaments and garments. In terms of architecture, the shrine with the polylobate arched doorway is similar to those carved in wood in the $11^{\text {th }}$ century portals of Tholing (Fig. 5).18

A similar shrine with a polylobate doorway and tiered roof is also found on an illumination from a fragmentary page (Fig. 6) ${ }^{19}$ where

17 Kashmiri apparel of the $10^{\text {th }}$ to $11^{\text {th }}$ century is well documented in sculptures see Pratapaditya Pal (2007), and in mural paintings photographed near Tholing by Tucci and Ghersi such as Mangnang (Tucci 1937) as well as recently discovered murals of this period in Tholing (see Fig. 2) as well as the cave temples of the Khartse Valley (Pritzker 2008, Tshe ring rgyal po and Papa-Kalantari, in cooperation with Jahoda 2009), and the sanctuary of Tabo (Klimburg-Salter 1997). Fo contemporary manuscripts see notably the discussions of the Tholing illuminations by Pratapaditya Pal (1988: 140-50) and the Prajñāpāramitā of Poo studied notably by Eva Allinger 2006 and Allinger, Tsering Gyalpo and Kalantari 2012.

18 For a polylobate doorway in manuscript illuminations see Prajñāpāramitā manuscript page with three enshrined figures of Buddha, Prajñāpāramitā and a Tibetan monk, illustrated as fig. 113 in Pal 2007 as well as the wooden sculpture of Tāă, $10^{\text {th }}-11^{\text {th }}$ century, now conserved in the Metropolitan Museum of Art (1994.488), also illustrated in Pal 2007: fig. 42.

19 The illumination on the manuscript fragment measures $8 \times 9 \mathrm{~cm}$. On the reverse there are traces of carbon and burn, thus it apparently was from a sheet of paper which was saved from a fire. On the back are several numerals and words 
Prajñāpāramitā is represented wearing Kashmiri apparel, hair ornaments and jewelry inside a brightly colored shrine. This illumination of Prajñāpāramitā also represents her inside the distinctive circular rainbow halo with gold leaf immediately surrounding the goddess. Her jewelry follows the models observed in the Prajñapaaramitā of IsIAO $1329 \mathrm{O}$ and the mural paintings of the goddesses and Bodhisattva inside the Tholing stūpa, where double or triple strands of pearls are draped as a torsade necklace as well as belts (see above Fig. 2). In both illuminations, there is a wide blue line framing the sides and the top of the square shape of the illumination, while the base has three stripes of color.

It is important to note that in terms of the textual basis for the iconography of Prajñāpāramitā there are two rituals in the Tibetan text of the Sädhanamālā, for the yellow and white aspects of Prajñāpāramitā. The yellow Prajñāpāramitā is to be represented with four arms, seated in vajraparyañkāsana, holding her principal hands over her heart forming the dharmacakramudrā of teaching and the two secondary hands holding the book and the prayer beads (mālā), exactly as represented on the fragment of the manuscript in the private collection (Zurich). The aspect of Prajñāpāramitā with four arms, her principal hands forming the dharmacakramudrā and the secondary hands holding the book and the vajra as represented on manuscript $1329 \mathrm{O}$ is not found in the recensions of the Sädhanamālä, either in Tibetan or in Sanskrit. ${ }^{20}$ The six-armed aspect represented on the leaf of the Śatasāhasrikā Prajñāpāramitā (Fig. 1), where the upper right hand holds a vajra, is also not found in the rituals now extant, although several representations are documented among sculptures, manuscripts and mural paintings produced in $\mathrm{mNga}^{\prime}$ ris skor gsum and Kashmir. ${ }^{21}$ Perhaps the ritual evocations for these as-

in Tibetan script (one cannot determine if archaic script or added later). On the back can be read the word deb (book) and 22 nga; several times the number 22 is repeated. There are also several illegible letters. "22 nga" would possibly refer to page 22 of volume 4 (vol. Nga) of a series of Prajñäpäramitäs (often ten refer to page 22 of volume 4 (vol. Nga)
volume sets). Private collection, Zurich.

20 See de Mallmann (1986: 306) for the four-armed yellow Prajñāpāramitā described in three Sanskrit sādhanas, and the Sädhanamälä of the Fourth Panchen Lama (in Tibetan; see bsTan pa'i nyi ma phyogs las rnam rgyal 1974: 862-64, sādhana 108, Sher phyin ma ser mo).

21 For mural paintings see Pal and Fournier 1982: D19 for six-armed white and S 66 for six-armed white Prajñāpāramitā; in Mangyu, cf. Peter van Ham (2010: 153) for a six-armed white Prajñāpāramitā with mālā and pothi. For manuscripts, see the six-armed yellow Prajñāāramitā illustrated in Huo Wei 2003 . 15 opposite ig. 15 opposite p. 69. For sculptures, see notably the unusual aspect identified as a "Buddhist Goddess" in Pal 1975: 180-81, ostensibly to be identified as a four-armed yellow Prajñāpāramitā, holding the pothi, the vajra, a lotus stem and her principal right hand over her heart holding a mālä. pects of Prajñāpāramitā with four or six arms, holding the vajra, were popular teachings which were locally practiced in the region, but not incorporated into the major corpus of ritual for reasons which cannot at present be determined.

In this fragmentary illumination of Prajñāpāramitā, the white guardian lions with shaggy manes flank the vertical columns rather than the apex of the shrine as in the shrine of Prajñāpāramitā on IsIAO 1329 O. In the illumination of the Buddha on IsIAO 1329 O, the lions are represented directly flanking the Buddha and his lotus cushion. In all cases, the lions appear playful rather than fierce, whether rampant or crouched, typically with gaping mouth to reveal four large stylized fangs that do not look sharp at all! This model of lion is recalls the musculature and physiognomy of those carved in wood in the triangular panel of the doorway of the Alchi Dukhang as photographed by Tucci (Fig. 7), while the doorway arch is directly related to the architecture of the Buddha illumination on manuscript 13290.

The gold-bodied Buddha (Fig. 8) performs the dharmacakramudrā as he is seated in vajraparyankāsana inside a shrine protected at the gables by crowned kinnaras and at the base by joyous lions with green, i.e. turquoise manes. The tailfeathers of the kinnaras rise to surround a jewel finial at the apex of the triangular door panel. A circular rainbow halo surrounds the gold body halo of the Buddha. His ușniṣa is spherical, coming to a slight point adorned by a minute disc with a flame, respectively symbolic of the moon and sun. His face is full, again the effect of volume is somewhat attenuated by the thick gold, although fine lines of red are used for emphasis (for the lower eyelid, the lips, the ears). His forehead is broad, the widow's peak hairline is parted at the very center, as is characteristic of the Bodhisattva in the murals of the Tholing stūpa (Fig. 2). His red monastic robes have a contrasting blue fabric neckline, draped in cowl neckline at mid-torso. Buddha figures wearing robes identical both for the contrasting color hem and manner of drapery with cowl neck are the sole traces of the AD 996 foundation phase of painting of the Tabo ambulatory. ${ }^{22}$ Likewise, the Khorchag monastery was also founded in 996 - while no murals of the foundation phase are now extant, a manuscript leaf discovered at Khorchag further documents this style of robe and drapery (Fig. 9). ${ }^{23}$ The codicological factors as well as the aesthetic matrix of this manuscript leaf tend to indicate a date within the $11^{\text {th }}$ century and possibly within the context of royal

22 See Klimburg-Salter 1996: fig. 15, p. 332.

23 Amy Heller thanks Tsering Gyalpo for kindly authorizing reproduction of this photograph (personal communication 29 May 2014), illustrated as fig. 137 in Tsering Gyalpo, Jahoda, Kalantari and Sutherland 2012. 
commission, although the leaf found at Khorchag displays less abundant use of gold than the Tholing manuscripts.

The iconographic identification of the Buddha is proposed to be either an aspect of Buddha Śäkyamuni teaching or as an aspect of Vairocana due to the gold body color, the lions, and the dharmacakramudrā (Heller 2010: 58-62). This hypothesis of identification as Vairocana is reinforced by the crescent disc of the moon and the flame of the sun at the apex of his ușnișa. Vairocana is understood to be a visual representation of the dharmakayya, literally the body of the Buddha's teachings, which is conceived as immanent formless and timeless; simultaneously the stūpa, as a reminder of the physical presence of the historic Buddha Śākyamuni, is also regarded as a representation of the dharmakāya. The sun and moon symbols above the usnissa are precisely the uppermost adornments of the stūpa, thus the body of this golden Buddha is a conflation of the visual representation of Vairocana as dharmakāya and the stūpa as dharmakäya. This phenomenon is not unique. In mural paintings, representations of Buddha having the sun moon finial of the ușnissa have been identified in Nako (Himachal Pradesh), and in Ladakh, near the monastery of dPe thub founded in 1036 by a scion of the Guge-Purang royal family (Vitali 1996: 301 ) at the nearby cave sanctuary of Brag khung Kha ba che, both times in murals painted in the Kashmiri aesthetic matrix (van Ham 2011: 54, fig. 8d). It has also been observed in a manuscript illumination of a gold Buddha represented underneath the Bodhi tree, thus ostensibly Śăkyamuni, on a leaf acquired at Tholing acquired by Ghersi, now conserved in the Cleveland Museum of Art, and a mural painting of the Buddha underneath the Bodhi tree at Tholing (Fig. 10, Tholing mural fragment). ${ }^{24}$

To conclude, this study of the illuminated leaf 1329 O of the Śatasāhasrikā Prajñāpāramitā from Tholing, now part of the Tucci archive of the IsIAO, Roma has led to towards understanding of the innovation in terms of aesthetics and technical prowess at manuscript illumination at Tholing under the aegis of the dynasty of GugePurang. One aspect appears to be the use of gold surround due to local and abundant gold resources which funded the early kingdoms of Guge-Purang; further it is the adaptation of this resource to the technique of illumination on paper support, which was refined in the western Himalayas with local plants and paper manufacture techniques. While the religious milieu was multi-cultural, the pre-

24 Amy Heller thanks Tsering Gyalpo for this reference: Wang Hu'e and Phun ${ }^{24}$ Amy Heller thanks Tsering Gyalpo for this reference: Wang Hu'e and Phun
tshogs rnam rgyal 2002: 77 and plate F11 where the flame finial may be obtshogs rnam rgyal 2002: 77 and plate F11 where the flame finial may be ob-
served. In the photograph by Liao Yang, the finial of the Buddha's ușnișa has been restored. dominant aesthetic matrix during this exceptional period of extreme refinement and glorification of these images to honor the royal commitment to the re-establishment of Buddhism in $\mathrm{mNga}^{\prime}$ ris skor gsum is Kashmiri.

\section{BIBLIOGRAPHIC REFERENCES}

ALLINGER, Eva. 2006. Künstler und Werkstatt am Beispiel des westtibetischen Manuskriptes in Poo/Himachal Pradesh. In: Mevissen, Gerd J. R. and Klaus Bruhn (eds) Vanamāla. Festschrift A. J. Gail. Berlin: Weidler, 1-8.

Allinger, Eva, TSERING GYALPO and Christiane KALANTARI. 2012. Illuminated manuscripts. In: Tsering Gyalpo, Christian Jahoda, Christiane Kalantari and Patrick Sutherland, with contributions by Eva Allinger, Hubert Feiglstorfer and Kurt Tropper, 'Khor chags / Khorchag / Kuojia si wenshi daguan [Kuojia Monastery: An Overview of Its History and Culture]. Lhasa: Bod ljongs bod yig dpe rnying dpe skrun khang [Old Tibetan Books Publishing House], 202-11.

ChAKRABARTI, Jayanta. 1980. Techniques in Indian Mural Painting. Calcutta: K.P. Bagchi.

DE ROSSI FILIBECK, Elena. 1996. Note on a manuscript from the Tucci Collection in the IsIAO Library. In: East and West, 46/3-4: 485-87.

- 2003. Catalogue of the Tucci Tibetan Fund in the Library of IsIAO, Vol. 2. Roma: Istituto Italiano per l'Africa e l'Oriente.

- 2007. The fragmentary Tholing $b K a^{\prime}$ 'gyur in the IsIAO Library. In: Kellner, Birgit et al. (eds) Pramānakïrtih: Papers Dedicated to Ernst Steinkellner on the Occasion of his 70th Birthday. Part I. (Wiener Studien zur Tibetologie und Buddhismuskunde, 70.1). Vienna: Arbeitskreis für tibetische und buddhistische Studien Universität Wien, 53-62.

ENG, Charlotte. 2013. Examination of an ink drawing by Vincent van Gogh. In: Journal of Paper Conservation, 14/4: 19-25.

VAN HAM, Peter. 2010. Heavenly Himalayas: The Murals of Mangyu and Other Discoveries in Ladakh. Munich etc.: Prestel.

_. 2011. Ladakh's missing link, the murals of Tragkhung Kowache. In Orientations, 42/5: 50-57.

HARRISON, Paul. Notes on some West Tibetan manuscript folios in the Los Angeles County Museum of Art. In: Kellner, Birgit et al. (eds) Pramānakirtih: Papers Dedicated to Ernst Steinkellner on the Occasion of his 70th Birthday. Part I. (Wiener Studien zur Tibetologie und Buddhismuskunde, 70.1). Vienna: Arbeitskreis für tibetische und buddhistische Studien Universität Wien, 229-245.

_. 2009. Tabo Studies III. A Cataloque of the Manuscript Collection of Tabo Monastery. Volume I: Sūtra Texts (Śer phyin, Phal chen, dKon brtsegs, mDo sde, Myan 'das). Edited by Cristina Scherrer-Schaub and Paul Harrison. Serie Orientale Roma. Roma: IsIAO. 
HeLleR, Amy. 2010. Preliminary remarks on the donor inscriptions and iconography of an $11^{\text {th }}$-century mchod rten at Tholing. In: Lo Bue, Erberto and Christian Luczanits (eds) Tibetan Art and Architecture in Context (Proceedings of the Eleventh Seminar of the IATS, Königswinter 2006). Halle, Saale: International Institute for Tibetan Studies, 43-74.

- 2014. Early paintings from West Tibet and the Western Himalayas in the Margot and Thomas J. Pritzker Collection. In: Orientations, 45/5: 36-49.

- 2015. An early thangka of Avalokiteśvara from the Kingdom of Guge. In: Journal of Tibetology, 10: 70-84.

- In press. Three ancient manuscripts from the Tucci Collection, IsIAO, Part I: Manuscript 1329 E. In: De Rossi Filibeck and Oscar Nalesini (eds) Proceedings of the 2014 Luciano Petech Centenary Symposium.

HeLMAN-WAŻNY, Agnieszka. 2014. The Archaeology of Tibetan Books. Leiden: Brill.

HUO WeI. 2003. Xizang Ali Zhada-xian Paerzong yizhi tanchengku de chubu diaocha. In: Wenwu, 568/9: 60-73.

JAMIESON, Robert Craig. 2000. The Perfection of Wisdom: Extracts from the Aștasahāsrikāprajñāpāramitā. New York: Viking Studio.

KARMAY, Samten Gyaltsen. 1980. An open letter by Pho-brang Zhi-ba-'od to the Buddhists in Tibet. In: The Tibet Journal, V/3: 3-28.

KLIMBURG-SALTER, Deborah. 1996. Style in Western Tibetan painting: The archaeological evidence. In: East and West, 46/3-4: 319-36.

—. 1997. Tabo, a Lamp for the Kingdom: Early Indo-Tibetan Buddhist Art in the Western Himalaya. Milan: Skira.

LALOU, Marcelle. 1954. Les manuscrits tibétains des grandes Prajñāpāramitā trouvés à Touen-Houang.. In: Silver Jubilee Volume of the ZinbunKagaku-Kenkyusyo. Kyōto: Kyōto University: 257-61.

—_. 1964. Manuscrits tibétains de la Śatasāhasrikāprajñāpāramitā cachés à Touen-houang. In: Journal Asiatique (1964): 479-86.

LOSTY, Jeremiah P. 1982. The Art of the Book in India. London: British Library.

DE MALLMANN, Marie-Thérèse. 1986. Introduction à l'iconographie du tântrisme bouddhique. Paris : A. Maisonneuve.

MELZER, Gudrun. 2014. A palaeographic study of a Buddhist manuscript from the Gilgit region: a glimpse into a scribes' workshop. In: Quenzer, Jörg B., Bondarev, Dmitry and Jan-Ulrich Sobisch (eds) Manuscript Cultures: Mapping the Field. Berlin: Walter de Gruyter, 227-74.

NYANG RAL NYI MA 'OD ZER. 1988. Chos 'byung me tog snying po sbrang rtsi'i bcud. [lHa sa:] Bod ljongs mi dmangs dpe skrun khang.

PAL, Pratapaditya. 1975. Bronzes of Kashmir. Graz: Akademische Druck- u. Verlagsanstalt.

_ 2007. The Arts of Kashmir. New York: Asia Society.
PAL, Pratapaditya. 2008. A painted book cover from Kashmir.

http://www.asianart.com/articles/kashmir/index.html (last access 10 Aug. 2015).

PAL, Pratapaditya and Lionel FouRnIER. 1982. A Buddhist Paradise: The Murals of Alchi. Hong Kong: Ravi Kumar/Visual Dharma Publications.

PAL, Pratapaditya and Julia MEECH-PEKARIK, 1988. Buddhist Book Illuminations, New York: Ravi Kumar Publisher and West Sussex: Richard Lyon-Chimera Books.

PRITZKER, Thomas J. 2008. The wall paintings of Nyag Lhakhang Kharpo In: Orientations, 39/2: 102-12.

RA SE DKON MCHOG RGYA MTSHO. 2004. Btsan po khri lde srong gtsug btsan gyi bka' gtsigs kyi yi ge thor bu. In: Bod ljongs zhib 'jug, 2 (2004): 117-25.

VAN SCHAIK, Sam. 2007. Tales from the Scriptorium I and II.

http:// earlytibet.com/2007/06/15/scriptorium/Catalogue (last access 10 Aug. 2015).

VAN SCHAIK, Sam, Helman-WAŻNy, Agnieszka and Renate Nöller. 2015. Writing, painting and sketching at Dunhuang: assessing the materiality and function of early Tibetan manuscripts and ritual items. In: Journal of Archaeological Science, 53 (January 2015): 110-32.

SCHERRER-SCHAUB, Cristina A. 1999. Was Byan chub sems dpa' a posthumous title of king Ye śes 'od? The evidence of a Tabo colophon. In: Scherrer-Schaub, Cristina A. and Ernst Steinkellner (eds) Tabo Studies II: Manuscripts, Texts, Inscriptions, and the Arts (Serie Orientale Roma, LXXXVII). Rome: IsIAO, 207-225.

SCHERRER-SCHAUB, Cristina and George BONANI. 2008. Establishing a typology of the old Tibetan manuscripts: a multidisciplinary approach. In: Klimburg-Salter, Deborah et al. (eds) The Cultural History of Western Tibet. Wien: China Tibetology Research Center, Arbeitskreis für tibetische und buddhistische Studien Universität Wien, 299-338 (first published in Whitfield, Susan (ed.) Dunhuang Manuscript Forgeries. London: The British Library: 184-215).

SHASTRI, Lobsang. 1997. The fire dragon chos 'khor (1076 AD). In: Krasser, Helmut et al. (eds) Tibetan Studies: Proceedings of the 7th Seminar of the International Association for Tibetran Studies, Graz 1995, Volume II. Vienna: Austrian Academy of Sciences Press, 873-82.

TAKEUCHI, Tsuguhito. 1995. Old Tibetan Contracts from Central Asia. Tokyo: Daizo Shuppan.

BSTAN PA'I NYI MA PHYOGS LAS RNAM RGYAL (Panchen Lama IV). 1974. Sadhana-mala of the Panchen Lama Bstan-pahi-ni-ma-phyogs-lasrnam-rgyal: Entitled Yi-dam-rgya-mtshohi sgrub-thabs rin-chenhbyun-gnas-kyi lhan-thabs rin-ḥbyun don gsal. Reproduced by Lokesh Chandra from the collections of Raghu Vira (Śata-pițaka series, 210 and 211). New Delhi: International Academy of Indian Culture. 
TSERING GYALPO, Christian JAHODA, Christiane KALANTARI and Patrick SUTHERLAND; with contributions by Eva Allinger, Hubert Feiglstorfer and Kurt Tropper. 2012. 'Khor chags / Khorchag / Kuojia si wensh daguan [Kuojia Monastery: An Overview of Its History and Culture]. IHa sa: Bod ljongs bod yig dpe rnying dpe skrun khang.

TSHE RING RGYAL PO and Christiane PAPA-KALANTARI, in cooperation with Christian JAHODA. 2009. The Buddhist Monuments of Khartse Valley, Western Tibet. AAS Working Papers in Social Anthropology, Austrian Academy of Sciences, Vol. 9, http://epub.oeaw.ac.at/wpsa/wpsa9.pdf.

TUCCI, Giuseppe. 1937. Indian paintings in Western Tibetan temples. In: Artibus Asiae, 7/1-4: 191-204.

_ 1949. Tibetan Painted Scrolls. Roma: La Libreria dello Stato.

_ 1973. Tibet Archaeologia Mundi (translated by Jean Marcadé). Genève: Nagel.

_ 1988 [1932]. Rin-chen-bzan-po and the Renaissance of Buddhism in Tibet around the Millenium (Indo-Tibetica II), edited by Lokesh Chandra. New Delhi: Aditya Prakashan (translation of Indo-Tibetica II. Rin c'en bzan் po e la rinascita del Buddhismo nel Tibet intorno al mille. Roma: Reale Accademia d'Italia, 1933).

_ 1989 [1937]. Sadhus et Brigands du Kailash: mon voyage au Tibet occidental. Paris: Peuples du Monde (French translation of Tucci, Giuseppe. 1937. Santi e briganti nel Tibet ignoto: diario della spedizione nel Tibet occidentale 1935. Milano: Hoepli.)
TUCCI, Giuseppe and Eugenio GHERSI. 1996 [1934] Secrets of Tibet: Being the Chronicle of the Tucci Scientific Expedition to Western Tibet (1933). New Delhi: Cosmo (orig. published London: Blackie \& Son; translation of Tucci, Giuseppe and Eugenio Ghersi, Cronaca della missione scientifica Tucci nel Tibet occidentale. Roma: Reale Accademia d'Italia 1934).

TULADHAR-DOUGLAS, Will. 2009. Writing and the rise of Mahāyāna Buddhism. In: Schaper, Joachim (ed.) Die Textualisierung der Religion. Tübingen: Mohr Siebeck, 250-72.

VITALI, Roberto. 1996. The Kingdoms of Gu.ge Pu.hrang: According to mNga'.ris rgyal.rabs by Gu.ge mkhan.chen Ngag.dbang grags.pa. Dharamsala, India: Tho ling gtsug lag khang lo gcig stong 'khor ba' rjes dran mdzad sgo'i go sgrig tshogs chung.

WANG HUI and PENGCUOLANGJIE / WANG HU'E and PHUN TSHOGS RNAM RGYAL. 2002. Xizang Ali Diqu wen wu qiang jiu bao hu gong cheng bao gao / Bod ljongs mnga' ris sa khul rig dngos myur skyong las grwa'i snyan zhu / Rescue Report and Conservation Projects on Ali's Cultural Heritages in Xizang Autonomous Region. Beijing: Ke xue chu ban she / Tshan rtsal dpe skrung khang. 
Fig. 1: (Detail) Prajñāpāramitā with devotees, folio from a Śatasāhasrikā Prajñāpāramitā (The Perfection of Wisdom in 100,000 Verses), Tholing monastery, $11^{\text {th }}$ century; ink, opaque watercolor, and gold on paper; illustration: $47 / 8 \times 103 / 4$ in. $(12.4 \times 27.3 \mathrm{~cm})$; folio: $71 / 2 \times 261 / 8$ in. $(19 \times 66.3 \mathrm{~cm})$. Los Angeles County Museum of Art, from the Nasli and Alice Heeramaneck Collection, purchased with funds provided by the Jane and Justin Dart Foundation (M.81.90.6) (photo: Yosi Pozeilov).
Fig. 2: (Detail) Interior of Tholing stūpa with fragmentary statues and mural paintings, clay, pigments and gold, height of statue, ca. $170 \mathrm{~cm}$, ca. 1025 A.D. (photography by Zong Tong-Chang, courtesy of Wang Xinyang).

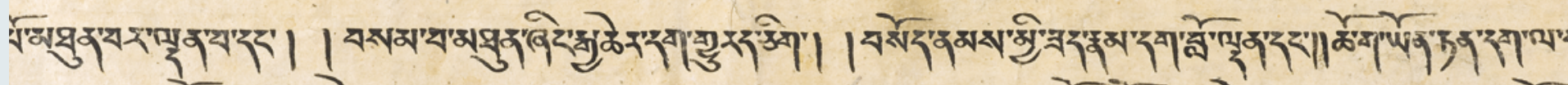

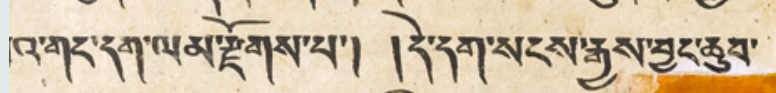

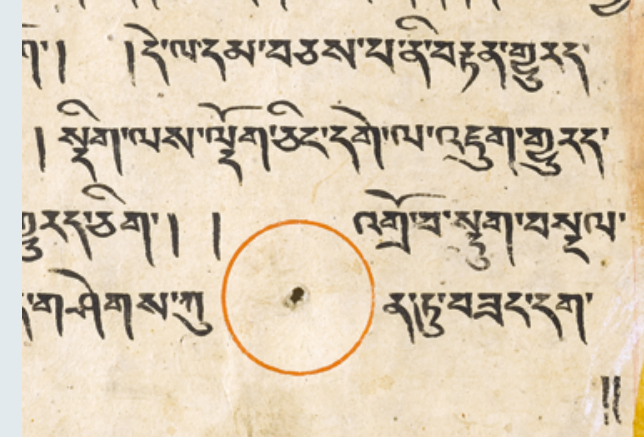

घुर

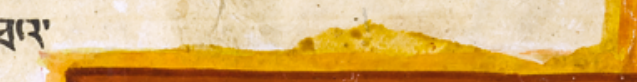

$$
11
$$

1

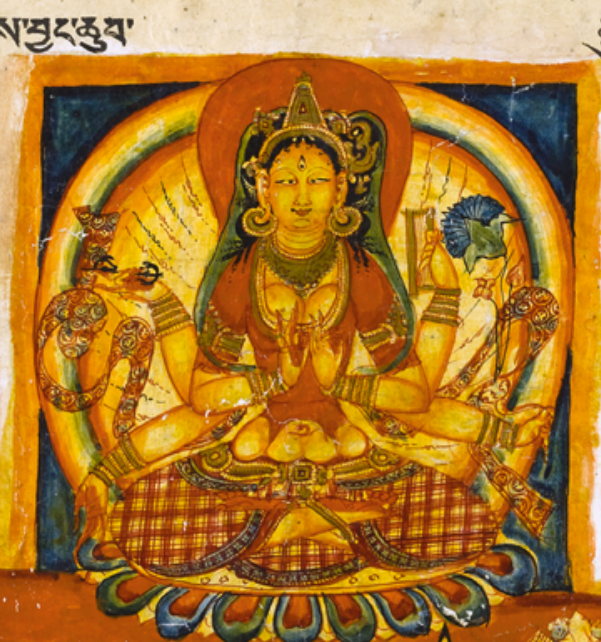

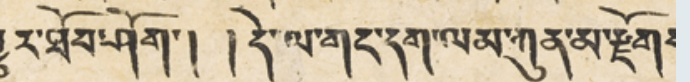

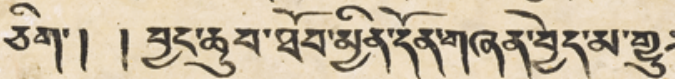

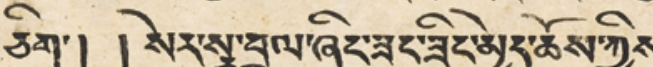

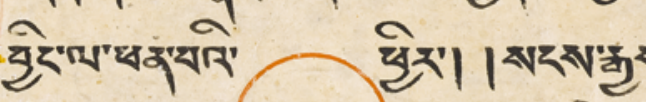

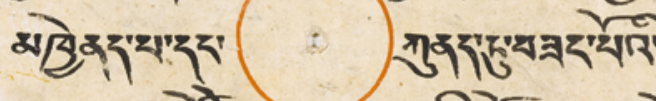

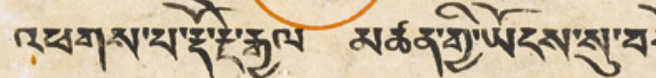

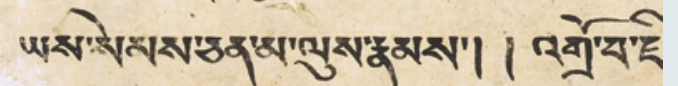
पर
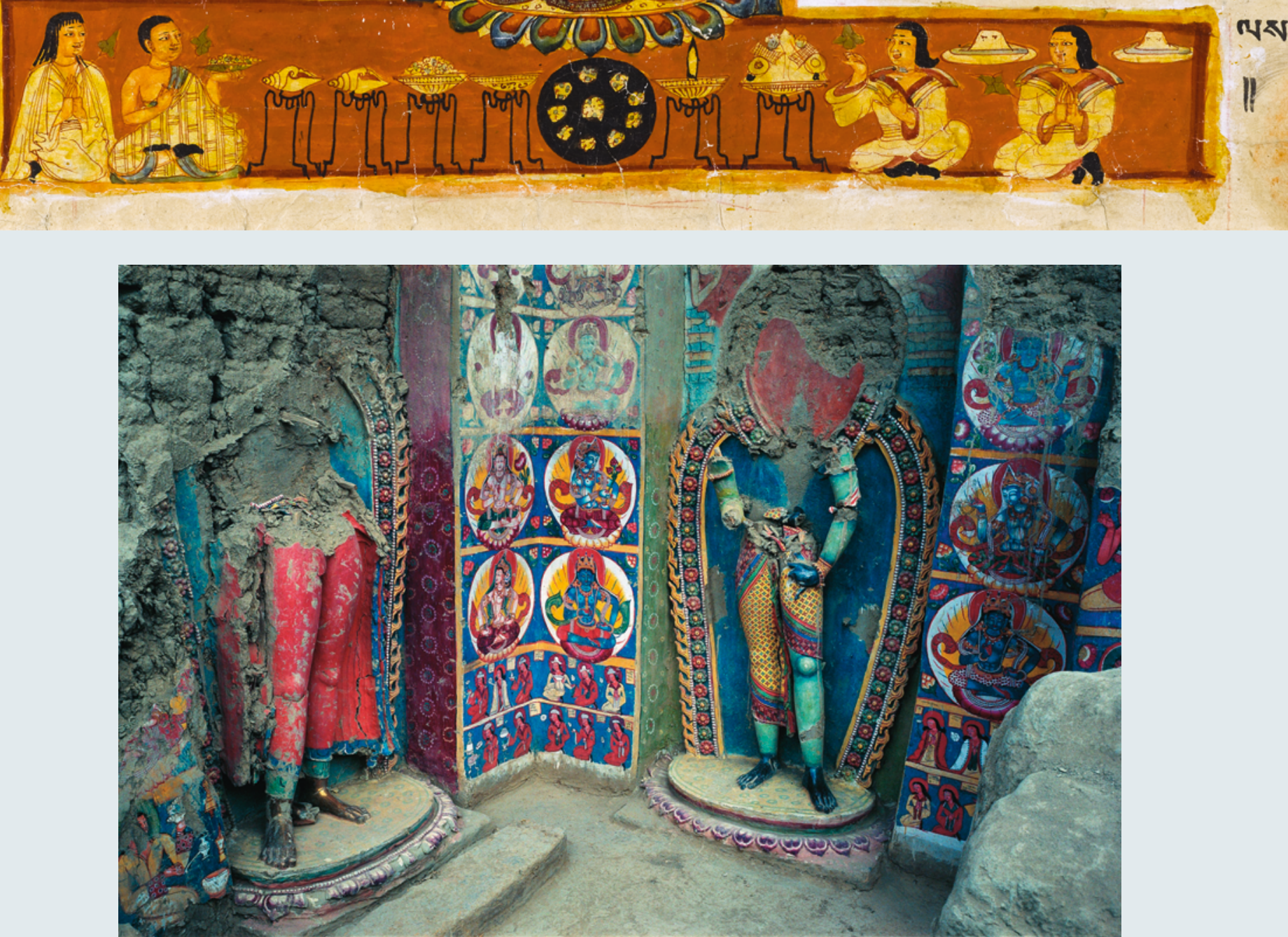


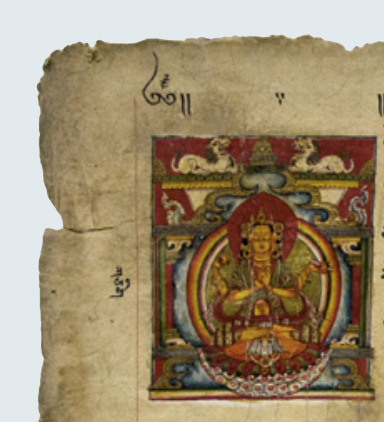

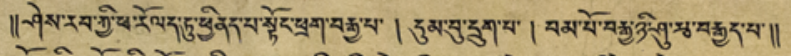

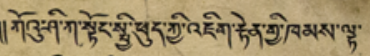

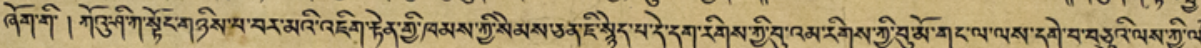

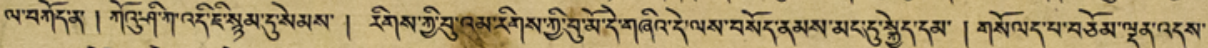

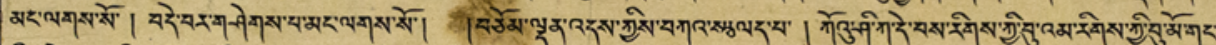

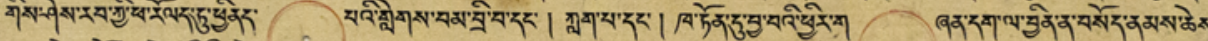

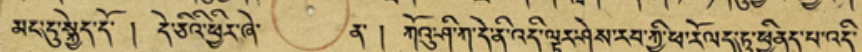

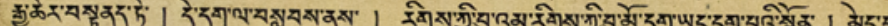

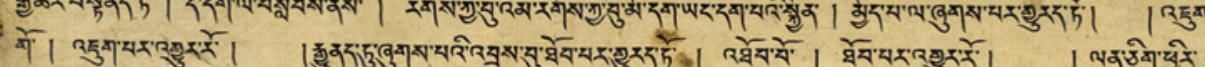

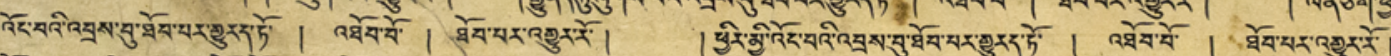

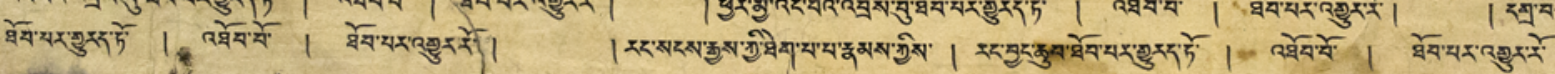
2.
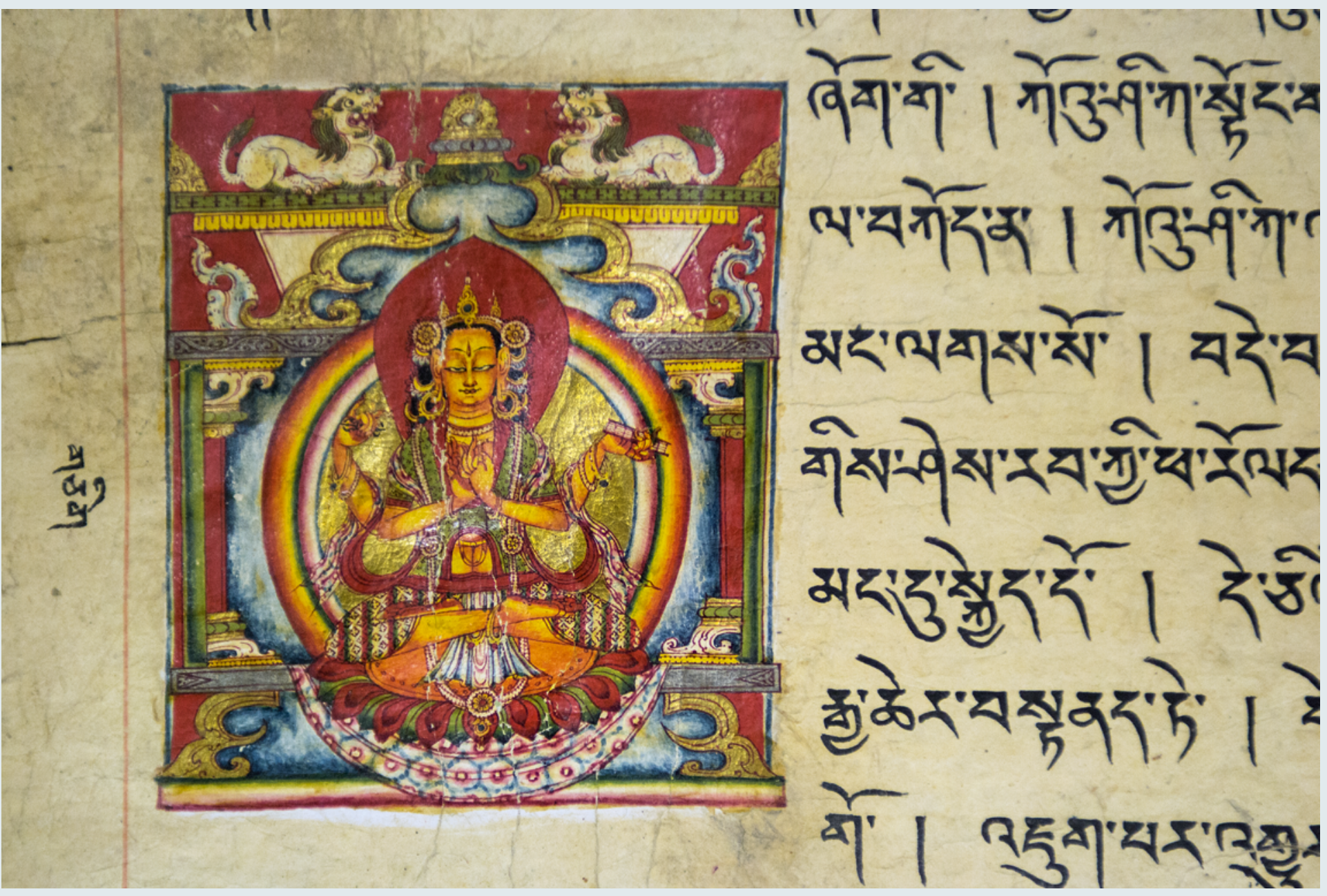

Fig. 3: Full leaf Śatasāhasrikā Prajñāpāramitā manuscript, ink, colors and gold on paper, $67 \times 20.5 \mathrm{~cm}$, $11^{\text {th }}$ century, IsIAO 1329 O, Roma (photography by Luigi Fieni).
Fig. 4: (Detail) Prajñāpāramitā of Śatasāhasrikā Prajñāpāramitā manuscript 1329 O, ink, opaque watercolor and gold on paper $(9.2 \times 8 \mathrm{~cm})$, IsIAO, Roma (photography by Luigi Fieni). 
Fig. 5: Sculpted doorway panels from Tholing ca. 1000 A.D., MNAO photographic archive, Giuseppe Tucci's collection, N 6019.3-4

(photography by Eugenio Ghersi, 1935; courtesy National Museum of Oriental Art, Rome).

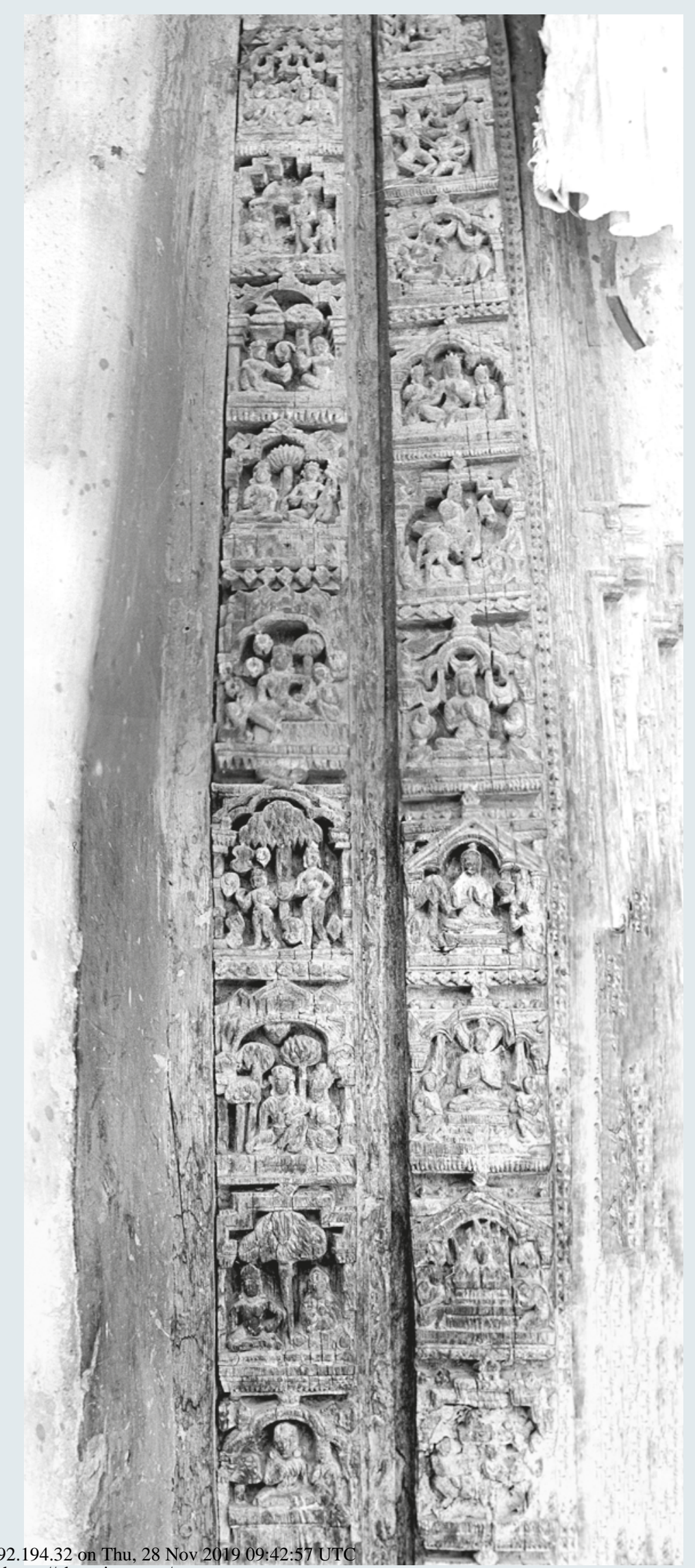



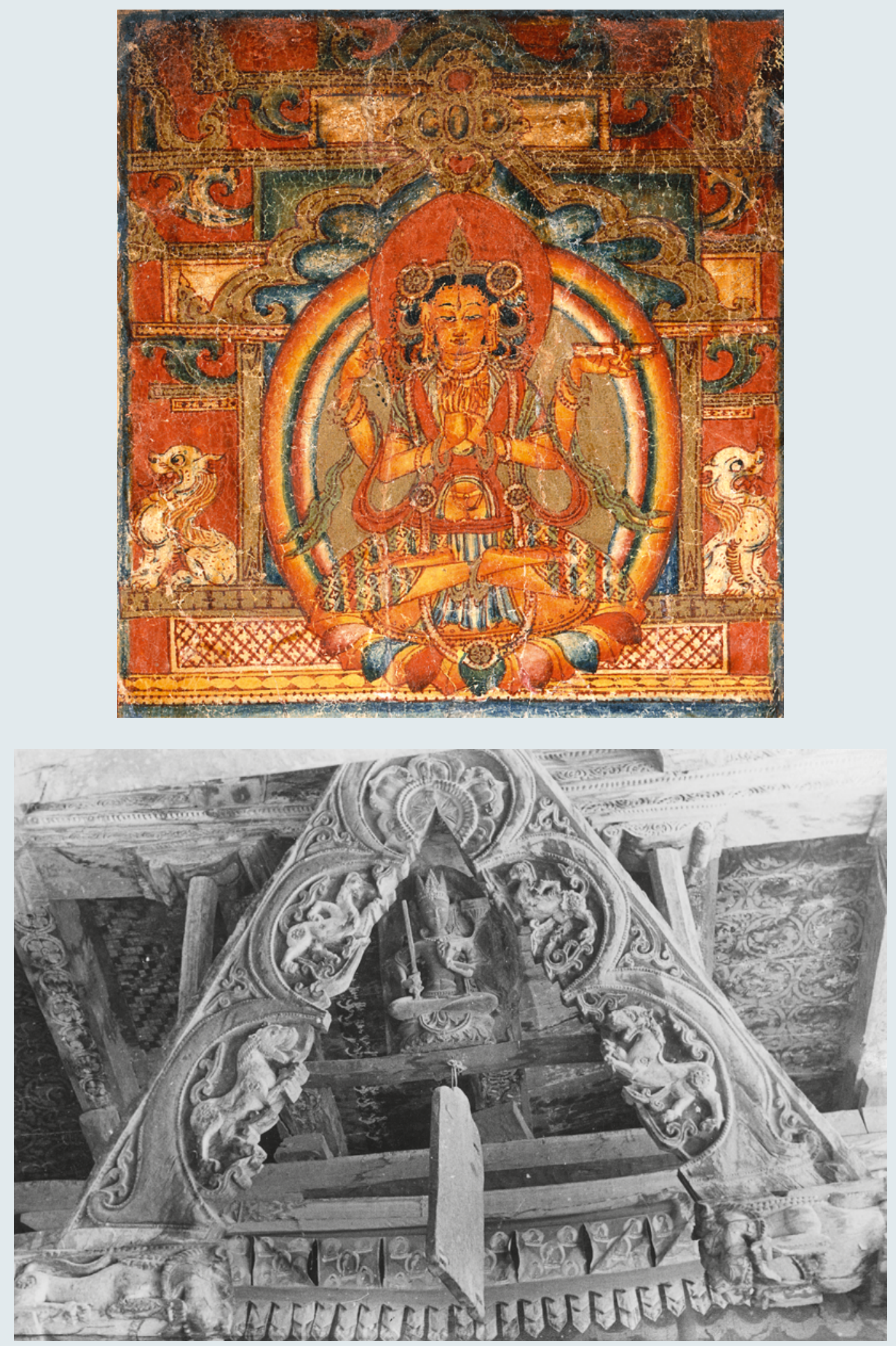

Fig. 6: Manuscript illumination of Prajñāpāramitā 4 arms with $m \bar{a} l a \bar{a}, 8 \times 9 \mathrm{~cm}$, ink, colors and gold on paper, $11^{\text {th }}$ century, private collection, Zurich (photography by Hughes Dubois).

Fig. 7: Doorway panel of Buddha and lions, Alch Dukhang, wood, late $11^{\text {th }}$ century, MNAO photographic archive, Giuseppe Tucci's collection, P 4413 (photography by Eugenio Ghersi, 1935; courtesy National Museum of Oriental Art, Rome). 


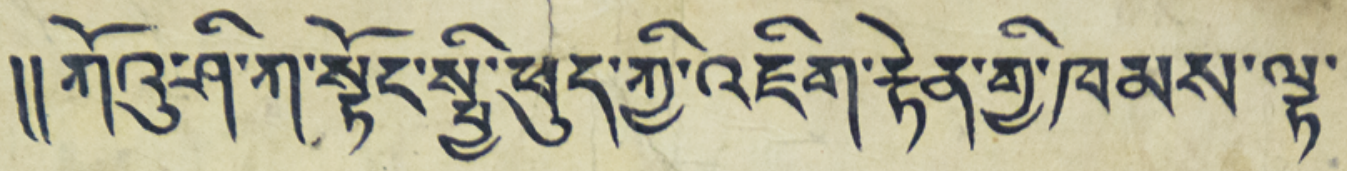

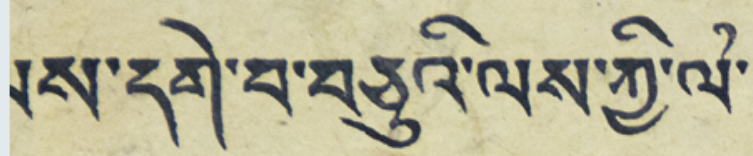

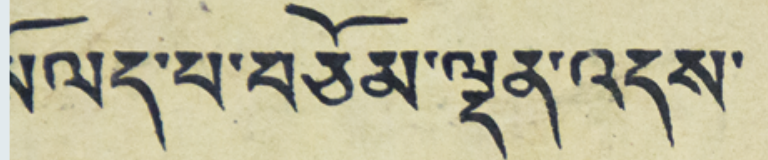
วิน

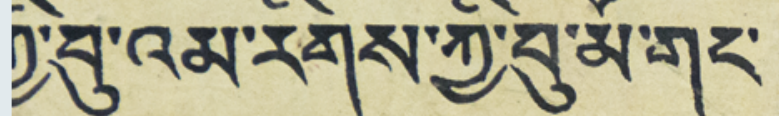
व रे

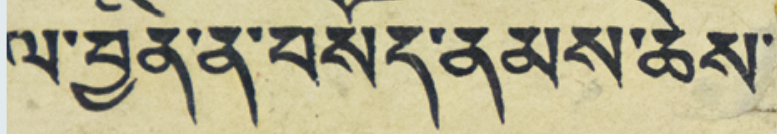

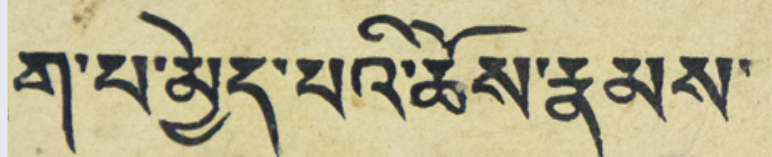
संखुरा

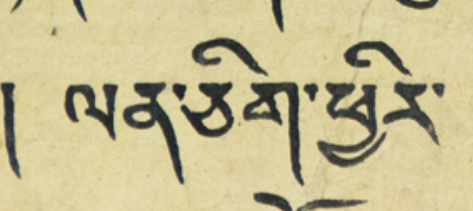

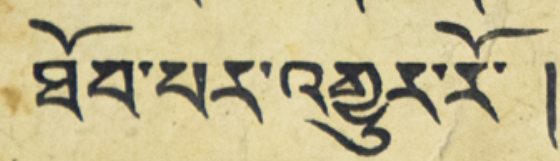

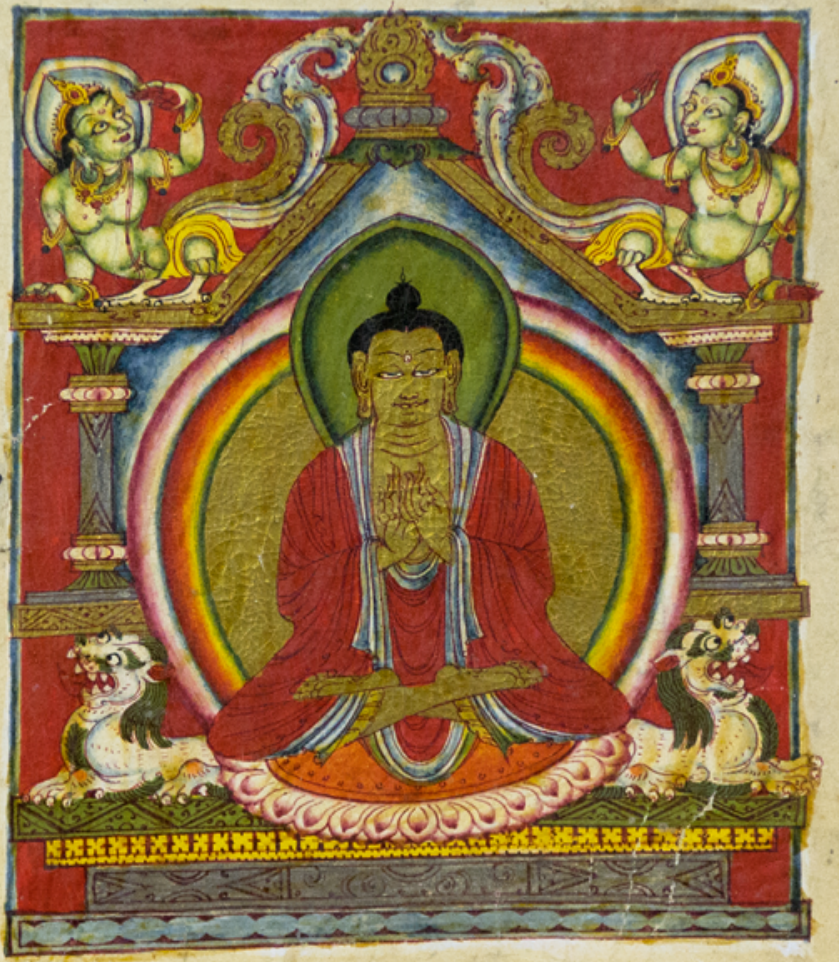

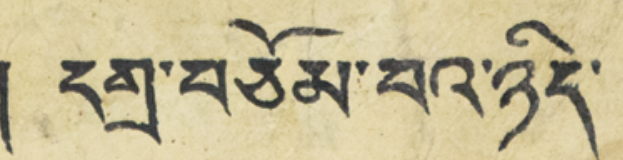




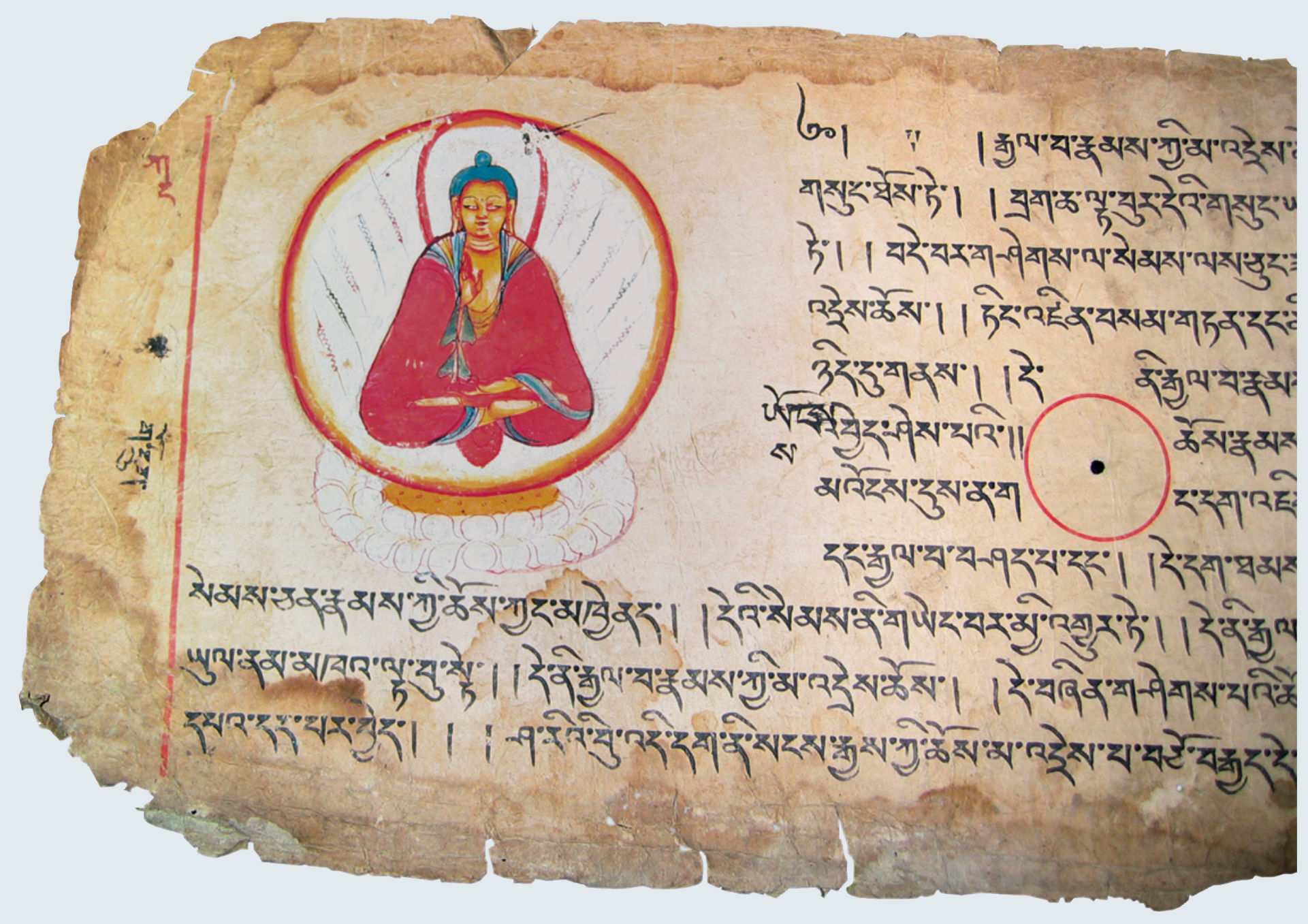

Fig. 9: (Detail) The Buddha illumination on a leaf of Śatasāhasrikā Prajñāpāramitā, Khorchag monastery, ink, colors and gold on paper, $11^{\text {th }}$ century (photography by Tsering Gyalpo, 2004). 
Fig. 10: (Detail) The Buddha under the Bodhi tree,

fragmentary mural painting, Tholing monastery,

$11^{\text {th }}$ century (photography by Liao Yang, 31 Aug. 2012).

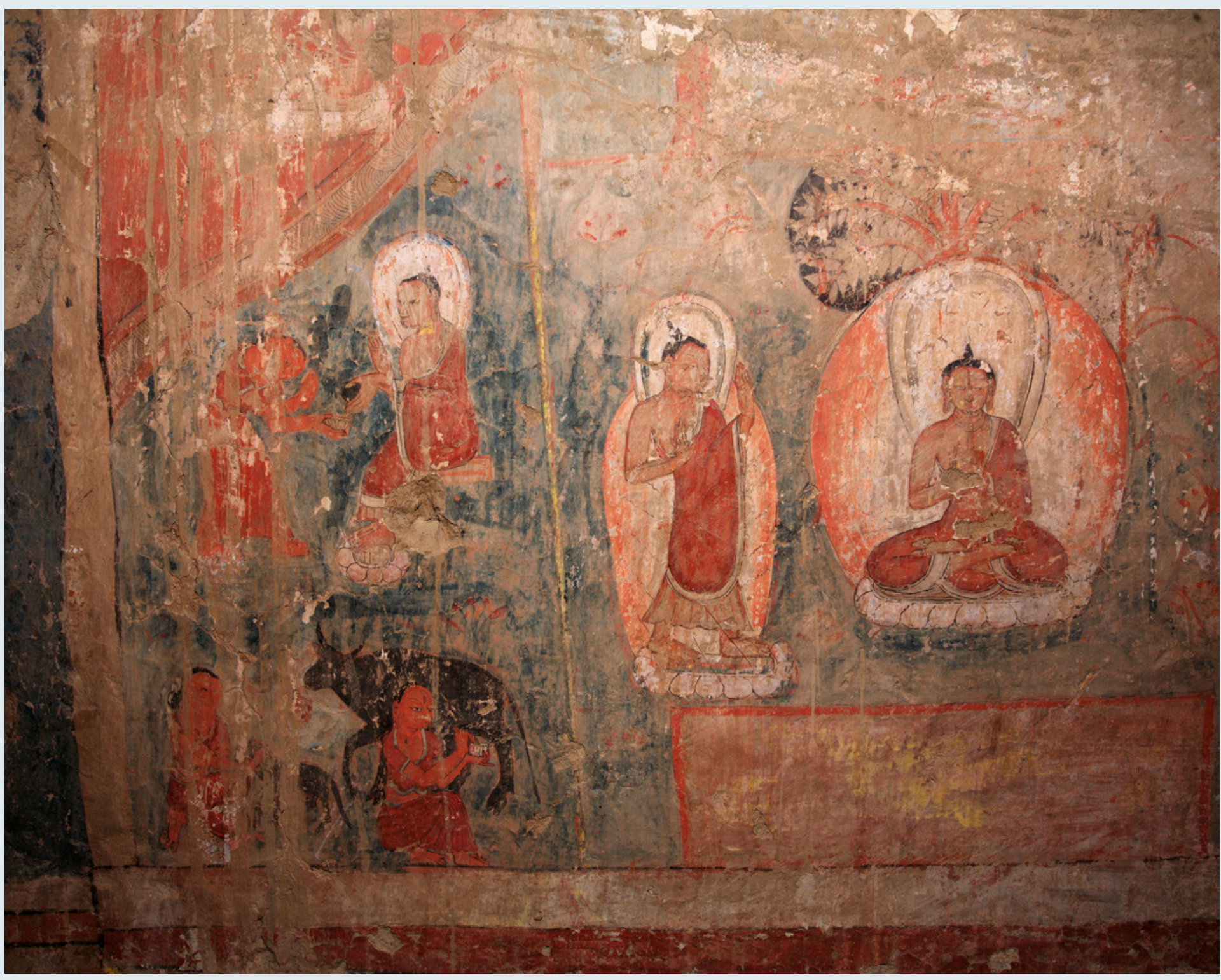


